\title{
Simulation of ignition delay time of compressed natural gas combustion
}

\author{
Yuswan Muharam ${ }^{1}$, Mirza Mahendra ${ }^{2}$, Dinda Gayatri' ${ }^{1}$ and Sutrasno \\ Kartohardjono $^{1^{*}}$
}

\author{
${ }^{1}$ Department of Chemical Engineering, Universitas Indonesia, \\ Depok 16424, Indonesia \\ *Email: sutrasno@che.ui.ac.id, \\ Phone: +62217863516; Fax: +62217863515 \\ ${ }^{2}$ Directorate General of Oil and Gas, \\ Ministry of Energy and Mineral Resources \\ Republic of Indonesia, Jakarta Indonesia
}

\begin{abstract}
This research mainly aims to simulate compressed natural gas $(\mathrm{CNG})$ combustion to create a valid reaction mechanism that can be used to determine the effects of temperature, pressure, equivalent ratio, diluents composition, and CNG composition on the ignition delay time profile in a combustion reaction. The combustion reaction involves many elementary reactions; therefore, in this study, the stages of important reactions were identified by sensitivity and rate of production analyses. In this study, CNG was represented by three components, namely, methane, ethane and propane $\left(\mathrm{CH}_{4} / \mathrm{C}_{2} \mathrm{H}_{6} / \mathrm{C}_{3} \mathrm{H}_{8}\right)$. The model is arranged according to the literature and validates the experimental data for $\mathrm{CH}_{4} / \mathrm{C}_{2} \mathrm{H}_{6} / \mathrm{C}_{3} \mathrm{H}_{8} / \mathrm{O}_{2} / \mathrm{N}_{2}$ mixture in the temperature ( $\mathrm{T}$ ) range of $1039-1553 \mathrm{~K}$, initial pressure $(\mathrm{P})$ range of $1.1-40.0 \mathrm{~atm}$, and equivalent ratio $(\phi)=0.5$, 1.0, and 2.0 using a shock tube. The software used in this study is Chemkin 3.7.1. The ignition delay time profile for CNG combustion has been successfully reproduced by the kinetic model. The slowest ignition delay time for the composition of $88 \% \mathrm{CH}_{4} / 8 \%$ $\mathrm{C}_{2} \mathrm{H}_{6} / 4 \% \mathrm{C}_{3} \mathrm{H}_{8}$ with an initial temperature range of $1100-1500 \mathrm{~K}$ is $37.2 \mathrm{~ms}(\mathrm{P}=2 \mathrm{~atm}$, $\mathrm{T}=1100 \mathrm{~K}$, and $\phi=2.0)$ and the fastest IDT is $0.033 \mathrm{~ms}(\mathrm{P}=30 \mathrm{~atm}, \mathrm{~T}=1500 \mathrm{~K}$, and $\phi=0.5)$. For constant ethane or propane composition, the increase in methane composition will cause slower ignition.
\end{abstract}

Keywords: Ignition delay time; combustion; $\mathrm{CNG}$; kinetic reaction model; simulation

\section{INTRODUCTION}

Natural gas, especially compressed natural gas (CNG), has emerged as one of the most popular alternative energy sources in industry. CNG affords several advantages such as low emissions, shows great promise in reducing emissions [1], competitive price, and low operation and maintenance costs [2]. The main component of CNG is methane, which has been in use in specific combustion devices like internal combustion engines and industrial gas turbines operated at high pressure and temperature [3]. CNG can be used in internal combustion engines, which are the key to the entire transportation sector [4], such as the Otto engine and diesel engine [5]. Meanwhile, the use of CNG in gas turbines is mainly for power plants, for either industry or the community [6]. The ignition delay time [7] is one of the most important parameters of an internal combustion engine. It is defined as the time from when fuel is injected into the engine until the fuel combusts. When fuel 
does not combust properly, it may cause knocking. Knocking can damage the engine; to prevent knocking in an Otto engine with a spark ignition system, auto-ignition must be prevented. To this end, it is necessary to determine the IDT. This paper discusses a simulation for collecting IDT data in an engine combusting CNG fuel. Combustion involves many reactions from the combination of all combustible elements in the fuel with oxygen [8]. The chemical kinetics mechanism is a system that consists of several elementary reactions with coefficient rates derived from basic kinetics experiments. The chemical kinetics mechanism for CNG combustion can be used to control factors such as the IDT in the ignition system. Because elementary reactions depend on temperature, IDT strongly depends on temperature as well. Each elementary reaction has a differential function. Such functions can be solved using Chemkin 3.7.1, which can alter the function of an elementary reaction that has been arranged into a differential equation and calculated numerically using a computer.

Lamoureux and Paillard [9] studied the IDT natural gas kinetics using a reflected shockwave at $1485-1900 \mathrm{~K}$ and $0.3-1.3 \mathrm{MPa}$ and with an equivalent ratio of $\phi=0.5-2.0$. Later, Walker conducted experiments using a shock tube and a simulation at 1223-2248 K and 0.65-1.42 atm and with equivalent ratios of $\phi=0.5$ and 1.0. Zhang et al. [10] conducted experiments and a kinetics to understand ignition for a mixture of methane and hydrogen at $900-1750 \mathrm{~K}$ and $1.8 \mathrm{MPa}$ and with $\phi=0.5-2.0$. Based on these experiments, kinetics studies were conducted under low pressure. One could also consider that ignition occurs under a large range, for example, in the auto-ignition process in a fuel engine. In this system, the fuel-air mixture enters the cylinder in a nearly ambient condition, and through a transient process, the pressure is increased from 10 to $40 \mathrm{~atm}$ and the un-ignition gas temperature increases from 1,000 to $1200 \mathrm{~K}$ [11]. Huang \& Bushe [12] conducted a simulation and an experiment to determine the IDT for a mixture of methane, ethane, and propane using a shock tube for a temperature range of 900-1400 $\mathrm{K}$ and pressure range of 16-40 bar. This study mainly aims to simulate CNG combustion to create a valid reaction mechanism that can be used to determine the effects of temperature, pressure, equivalent ratio, diluents composition, and CNG composition on the ignition delay time profile in a combustion reaction. In this experiment, a large pressure range was used, and high pressure values were achieved; however, the composition fuel contained various additives, making it difficult to understand the difference in the main components. Healy et al. [13] conducted an experiment using a shock tube and a simulated IDT for a temperature range of 1039-1553 $\mathrm{K}$, pressure range of 1.1-40 atm, and equivalent ratio range of $\phi=0.5-2.0$. This experiment serves as the reference for validating the mechanism. Thus, this focuses on creating a kinetics model for valid CNG ignition reaction and determining the IDT profile for CNG combustion for various initial $\mathrm{T}$ and $\mathrm{P}$ values, $\phi$ values, and diluents and CNG compositions.

The composition of natural gas varies with location. At several locations, natural gas contains impurities such as water $\left(\mathrm{H}_{2} \mathrm{O}\right), \mathrm{H}_{2} \mathrm{~S}$, and $\mathrm{CO}_{2}$, whose contents are beyond the specified limits; in such cases, natural gas requires specific operational equipment for processing. The specification of natural gas products is commonly stated in terms of their composition and performance criteria. The performance criteria include the heating value; inert total; and water, oxygen, and sulphur contents. The heating value is a criterion pertaining to natural gas combustion, whereas the other criteria pertain to the protection of pipes from corrosion and plugging. CNG is natural gas that has been compressed under high pressure. It is produced by compressing methane $\left(\mathrm{CH}_{4}\right)$ extracted from natural gas. $\mathrm{CNG}$ is stored and distributed in pressure vessels that are commonly cylindrical in shape. The volume of natural gas becomes $1 / 133^{\text {rd }}$ and $1 / 280^{\text {th }}$ the original when compressed to 
$98 \mathrm{~atm}$ and $200 \mathrm{~atm}$, respectively, at $293 \mathrm{~K}$. Compression is aimed at reducing the volume of natural gas, making it easy to transport. CNG supplied to consumers should have a composition that satisfies the specifications for commercial gas, such as the maximum limits for the water, $\mathrm{CO}_{2}$, and heavy hydrocarbon contents. Specifically, compressed gas has strict limitations pertaining to water and heavy hydrocarbon contents to prevent condensation and the formation of hydrates. Table 1 shows the typical CNG composition in various countries. This table shows that Indonesian natural gas contains $89.91 \%$ methane, $5.44 \%$ ethane, and $3.16 \%$ propane, while the remainder is a mixture of butane, pentane, and nitrogen.

Table 1. Typical CNG composition [14].

\begin{tabular}{|c|c|c|c|c|c|c|c|}
\hline \multirow[b]{2}{*}{ Components } & \multicolumn{7}{|c|}{ Typical CNG composition in various countries (\% volume) } \\
\hline & Alaska & China & Brunei & $\begin{array}{l}\text { Abu } \\
\text { Dhabi }\end{array}$ & Indonesia & Tennessee & Irvine \\
\hline Methane & 99.81 & 98.51 & 89.83 & 82.07 & 89.91 & 93.37 & 96.45 \\
\hline Ethane & 0.07 & & 5.89 & 15.86 & 5.44 & 3.58 & 1.34 \\
\hline Propane & & & 2.92 & 1.89 & 3.16 & 1.02 & 0.5 \\
\hline n-butane & & & 0.74 & 0.07 & 0.75 & 0.19 & 0.04 \\
\hline i-butane & & & 0.56 & 0.06 & 0.67 & 0.21 & 0.04 \\
\hline Pentane & & & 0.04 & & 0.03 & 0.06 & 0.01 \\
\hline Nitrogen & 0.12 & 0.43 & 0.02 & 0.05 & 0.04 & 0.87 & 0.45 \\
\hline $\begin{array}{l}\text { Carbon } \\
\text { dioxide }\end{array}$ & & 0.87 & & & & 0.7 & 1.34 \\
\hline Oxygen & & 0.05 & & & & & \\
\hline Water & & 0.14 & & & & & \\
\hline
\end{tabular}

In Indonesia, the Directorate General of Oil and Gas has stipulated specifications of CNG-type fuel for transportation and sale, as shown in Table 2.

Table 2. Indonesian specifications of CNG [15].

\begin{tabular}{cccc}
\hline \multirow{2}{*}{ Component } & \multirow{2}{*}{ Unit } & \multicolumn{2}{c}{ Limit } \\
& & Minimum & Maximum \\
\hline $\mathrm{C}_{1}$ & \% volume & 77.0 & \\
$\mathrm{C}_{2}$ & \% volume & & 8.0 \\
$\mathrm{C}_{3}$ & \% volume & 4.0 \\
$\mathrm{C}_{4}$ & \% volume & 1.0 \\
$\mathrm{C}_{5}$ & $\%$ volume & 1.0 \\
$\mathrm{C}_{6}$ & $\%$ volume & 0.5 \\
$\mathrm{~N}_{2}$ & $\%$ volume & 3.0 \\
$\mathrm{H}_{2} \mathrm{~S}$ & ppm vol & 10 \\
$\mathrm{Hg}$ & $\mu \mathrm{g} / \mathrm{m}^{3}$ & & 100 \\
$\mathrm{O}_{2}$ & $\%$ volume & 0.1 \\
$\mathrm{H}_{2} \mathrm{O}$ & $1 \mathrm{~b} /$ mmscf & 3.0 \\
$\mathrm{CO}_{2}$ & $\%$ volume & 5.0 \\
\hline
\end{tabular}




\section{MATERIALS AND METHODS}

The method involves developing a reaction kinetics model for CNG combustion, validating the model using experimental data, conducting sensitivity analysis of the model, and simulating the model.

\section{Development of Reaction Kinetics Model}

The kinetics model was developed using elementary reaction data, kinetics data, and thermodynamics data from literature [16]. The development of the reaction kinetics model is one of the steps toward validation of the reaction mechanism. The first step is analysing the sensitivity for several points on the IDT profile (experimental data). This sensitivity analysis is important for identifying elementary reactions, such as reactions categorized as sensitive reactions. Accordingly, the extent to which $A$ (pre-exponential factor) should be changed for important reactions is determined. The Aurora feature of Chemkin software is used to obtain the IDT profile for the CNG combustion system.

\section{Validation Mechanism}

In the case of compliance, the kinetics reaction model is validated with experimental data obtained using the shock tube. The data used is the IDT for the methane/ethane/propane combustion system. It is acquired from Healy's experiment [13] in 2008 with mixed $\mathrm{CH}_{4} / \mathrm{C}_{2} \mathrm{H}_{6} / \mathrm{C}_{3} \mathrm{H}_{8} / \mathrm{O}_{2} / \mathrm{N}_{2}$ at $1039-1553 \mathrm{~K}, 1.1-40 \mathrm{~atm}$, and equivalent ratios of $\phi=0.5,1.0$, and 2.0.

\section{Sensitivity Analysis and Rate Production Analysis}

The study of the oxidation and combustion kinetics reaction of the hydrocarbon model involved thousands of elementary reactions that constitute the complex reaction mechanism. Each elementary reaction rate in the combustion mechanism shows huge divergence. Some elementary reactions can affect the system result significantly if there is a change in the coefficient rate reaction. This elementary reaction is called the coefficient of limiting rate; therefore, sensitivity analysis was conducted to differentiate the limiting reaction rate from other elementary reactions. Meanwhile, rate production analysis was conducted by calculating the contribution percentage of reactions unrelated and related to the consumption of chemical species. For this analysis, the species distribution was observed. The percentage of species produced from several reaction methods was calculated using Chemkin [17]. Rate analysis was performed to find the contribution of reactions toward the consumption of $\mathrm{CH}_{4}, \mathrm{C}_{2} \mathrm{H}_{6}$, and $\mathrm{C}_{3} \mathrm{H}_{8}$ as well as to find the contribution of reactions toward the production of $\mathrm{CO}_{2}, \mathrm{CO}$, and $\mathrm{CH}_{2} \mathrm{O}$.

\section{Simulation}

The simulation is performed to determine the behaviour of the CNG combustion reaction without testing it in the laboratory. Specifically, the IDT profile is studied from the combustion reaction. The simulation was conducted using Chemkin 3.7.1 software, and was implemented on the kinetics reaction model already validated by varying the operation conditions. CNG combustion was simulated by varying the initial pressure, equivalent ratio, diluents composition, and $\mathrm{CNG}$ composition.

\section{Experiment Equipment and Materials}

The experiment also used the Chemkin 3.7.1 program. The materials used were selected based on the kinetics reaction model for CNG fuel combustion from the Lawrence 
Livermore National Laboratory (LLNL) kinetics model and thermodynamics data [16]. In addition to the kinetics model and thermodynamics data, the combustion simulation operation conditions are provided as input data to the Chemkin software.

\section{RESULTS AND DISCUSSION}

\section{Reaction Mechanism}

The chemical reaction mechanism of hydrocarbons consists of hundreds of elementary reactions. The detailed kinetics mechanism used consists of 5 elements, 155 species, and 689 reactions. The elements showed the chemical elements, the species showed the chemical compounds that contribute to the reactions for the reactants and products, and the reaction showed the elementary reaction together with the Arrhenius parameter.

\section{Mechanism Validation}

The mechanism was validated by comparing the IDT profile's simulation results obtained using Chemkin 3.7.1 and the experimental results. Healy et al. [13] had already conducted experiments to obtain the IDT for CNG combustion (methane/ethane/propane) from shock tube measurements. The chemical kinetics mechanism of methane/ethane/propane used in this was based on that used by LLNL [16]. From the numerical calculations performed using Chemkin 3.7.1, the IDT was determined as the time at which the radical concentration increased sharply. Figure 1 shows the $\mathrm{OH}$ mole fraction profiles versus time at $\mathrm{T}=1061 \mathrm{~K}, \mathrm{P}=20 \mathrm{~atm}$, and $\phi=0.5$. The $\mathrm{OH}$ concentration increased significantly at dwelling times of more than 3.81E-03 s, as shown in Figure 1. The $\mathrm{OH}$ radical is strong, and it can therefore be used as a parameter for fast or slow reactions. This may imply that before $3.81 \mathrm{E}-03 \mathrm{~s}$, the reaction was slow, which means that fuel was consumed slowly. However, beyond this dwelling time, the reaction was fast and ignition occurred owing to the significantly increased concentration of $\mathrm{OH}$ radicals.

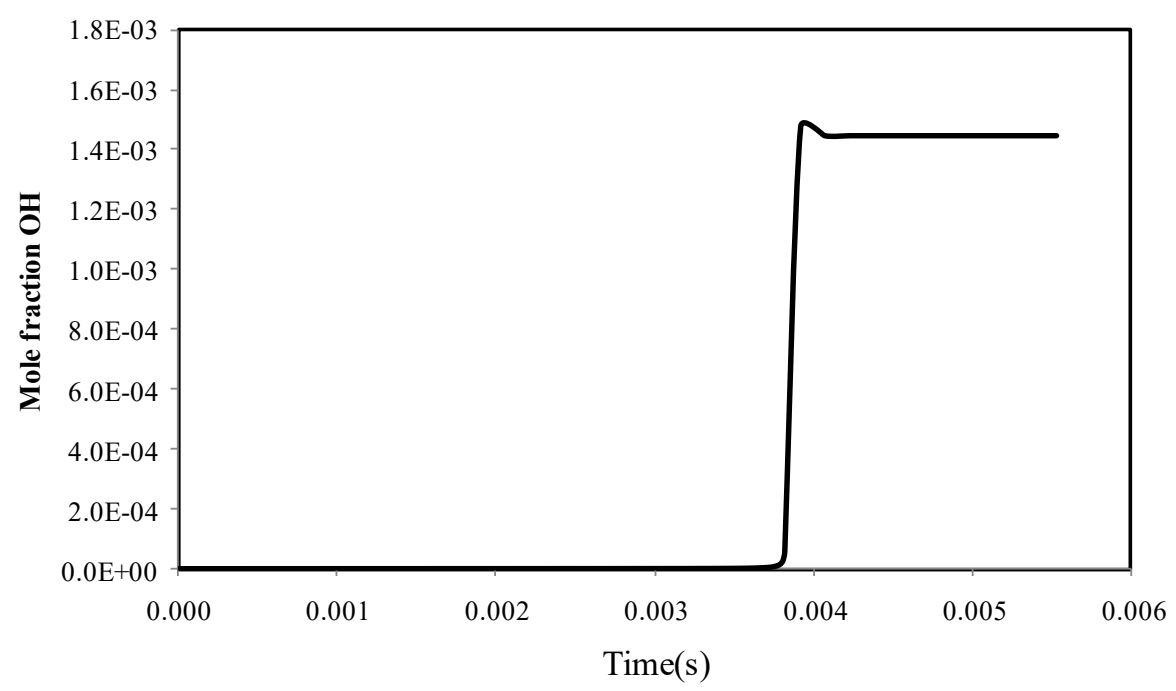

Figure 1. OH concentration from detailed kinetic model.

The validation process conducted using the LLNL kinetic mechanism model simulates pressure and temperature ranges similar to those observed under experimental conditions. The validation was conducted for five conditions in accordance with Table 3. Figure 2 shows a comparison of the experimental results with the simulation mechanism 
after the modification of the Arrhenius parameters. The model and the experimental data show good agreement, with the standard deviation being 0.06 . In addition, it is known that increasing the initial temperature reduces the IDT. This means that the higher the initial temperature, the faster is the ignition time. At higher pressure with the same equivalence ratio, the IDT would be smaller.

Table 3. CNG composition and operating conditions for various validations.

\begin{tabular}{cccccc}
\hline \multirow{2}{*}{ Validation } & \multicolumn{5}{c}{ Composition (\% volume) } \\
& $\% \mathrm{CH}_{4}$ & $\% \mathrm{C}_{2} \mathrm{H}_{6}$ & $\% \mathrm{C}_{3} \mathrm{H}_{8}$ & $\phi$ & $P[18]$ \\
\hline $\mathrm{A}$ & 90 & 6.6 & 3.3 & 1.0 & 1.2 \\
$\mathrm{~B}$ & 90 & 6.6 & 3.3 & 1.0 & 40 \\
$\mathrm{C}$ & 70 & 20 & 10 & 0.5 & 20 \\
$\mathrm{D}$ & 70 & 20 & 10 & 2.0 & 1.1 \\
$\mathrm{E}$ & 70 & 20 & 10 & 2.0 & 20 \\
\hline
\end{tabular}

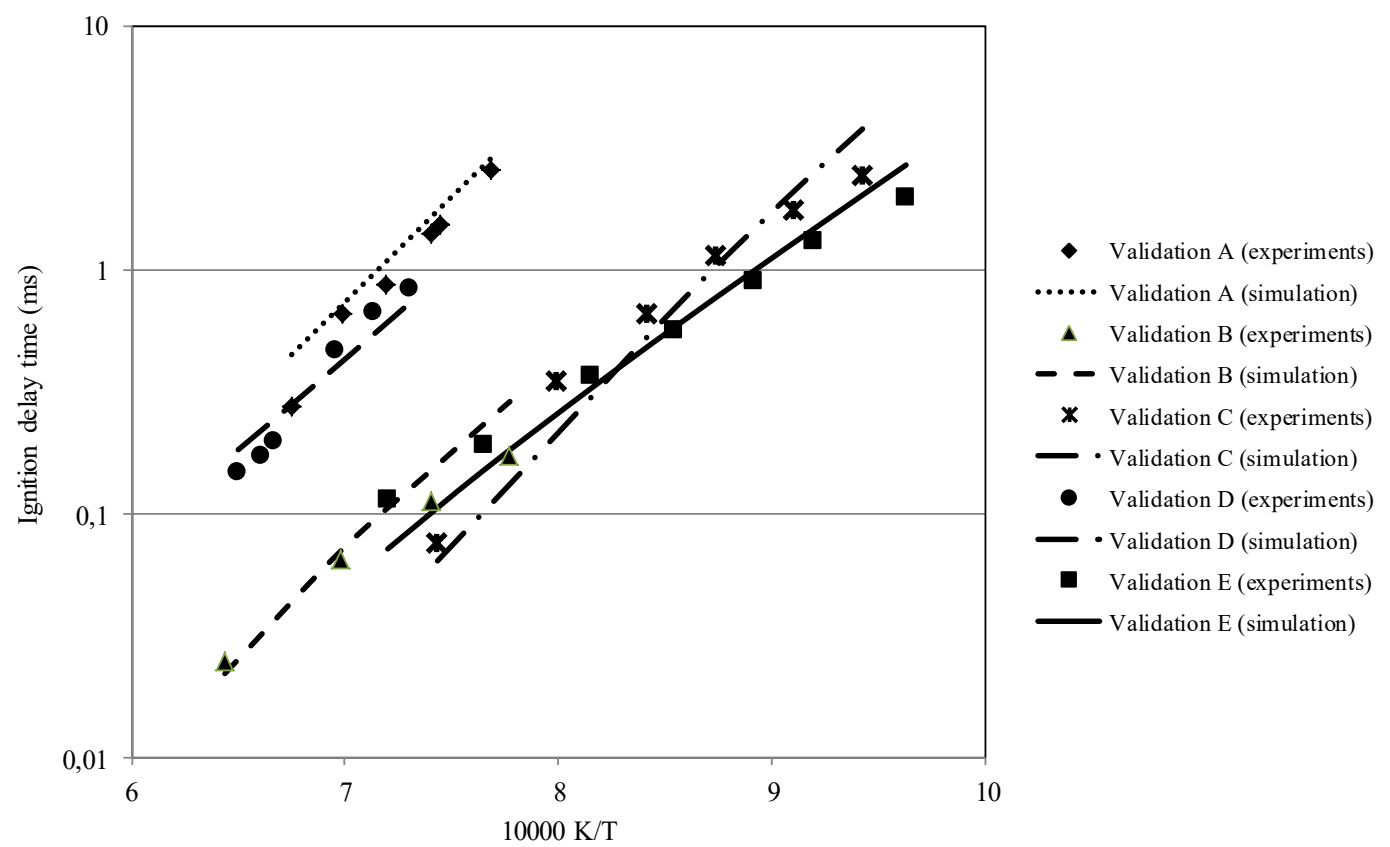

Figure 2. Comparison of experimental results (symbols) and simulation results after adjustment (line) for validating IDT A, B, C, D, and E.

\section{Sensitivity Analysis}

Table 4 presents the CNG compositions and operating conditions used for the analyses. The sensitivity analysis for different $\mathrm{T}$ was conducted at $20 \mathrm{~atm}, \phi=0.5$, and $1345 \mathrm{~K}$ (mixture 1) and 1,061 K (mixture 2). Figure 3 shows a comparison of the sensitivity analysis results. At $1345 \mathrm{~K}$, the most sensitive reaction is reaction 2, followed by reaction 34 . But at $1,061 \mathrm{~K}$, the most sensitive reaction is reaction 34 , followed by reaction 2. This indicates that the sensitivity of reaction 2 increases with $\mathrm{T}$. Reaction 2 , $\mathrm{O}+\mathrm{OH}<=>\mathrm{O}_{2}+\mathrm{H}$, to the right has a small activation energy $\left(E_{\mathrm{a}}\right)$, i.e., $0 \mathrm{cal} / \mathrm{mol}$. Therefore, the reaction to the left, $\mathrm{O}_{2}+\mathrm{H} \rightarrow \mathrm{O}+\mathrm{OH}$, is considered to have fairly large $\mathrm{Ea}$, as written in Bourque et al.'s mechanism [19], i.e., $16600 \mathrm{cal} / \mathrm{mol}$. This shows that reaction 2 was one of the controllers in the elementary reactions, because it occurred at high temperature. 
Therefore, the ignition was mainly governed by the chain branching processes (reaction 2). Meanwhile, at lower $\mathrm{T}$, reaction 34 (radical decomposition), $\mathrm{CH}_{3}+\mathrm{HO}_{2}<=>\mathrm{CH}_{3} \mathrm{O}+\mathrm{OH}$, was the most sensitive reaction. The reaction to the left, $\mathrm{CH}_{3} \mathrm{O}+\mathrm{OH} \rightarrow \mathrm{CH}_{3}+\mathrm{HO}_{2}, 24600 \mathrm{cal} / \mathrm{mol}$, is one of the controllers in the elementary reaction. Reactions 2 and 34 were the most sensitive reactions for different temperatures because these reactions are the basis of hydrocarbon combustion. The reaction to the right in reaction 34 also generated $\mathrm{OH}$ radicals, the most active radical in all the fuel burning processes. Reactions 31 and 133 (propagation reaction) also produce $\mathrm{OH}$ radicals at 1,345 $\mathrm{K}$. At 1,061 K, more $\mathrm{OH}$ radicals are produced by reaction 31 (propagation reaction) and reaction 23 (thermal decomposition reaction of hydrogen peroxide). Meanwhile, reaction 35 serves as the termination reaction for $\mathrm{CH}_{3}$ and $\mathrm{HO}_{2}$ radicals. This reaction had an inhibiting effect as it consumed two radicals. The sensitivity coefficient of reaction 35 was smaller for higher temperature (mixture 1) than for lower temperature (mixture 2). Therefore, at $20 \mathrm{~atm}$ and $\phi=0.5$, mixture 1 has a shorter IDT than mixture 2 . This is evident from the simulation results, which showed that the respective IDTs were 0.0644 and 3.81 ms.

Table 4. CNG composition and operating conditions for sensitivity analysis, production rate analysis, and consumption analysis

\begin{tabular}{ccccccc}
\hline $\begin{array}{c}\text { Mixture } \\
\text { No. }\end{array}$ & $\% \mathrm{CH}_{4}$ & $\% \mathrm{C}_{2} \mathrm{H}_{6}$ & $\% \mathrm{C}_{3} \mathrm{H}_{8}$ & $\phi$ & $P[18]$ & $T(\mathrm{~K})$ \\
\hline 1 & 70 & 20 & 10 & 0.5 & 20 & 1345 \\
2 & 70 & 20 & 10 & 0.5 & 20 & 1061 \\
3 & 70 & 20 & 10 & 2.0 & 20 & 1061 \\
4 & 70 & 20 & 10 & 2.0 & 20 & 1370 \\
5 & 70 & 20 & 10 & 2.0 & 1.1 & 1370 \\
\hline
\end{tabular}

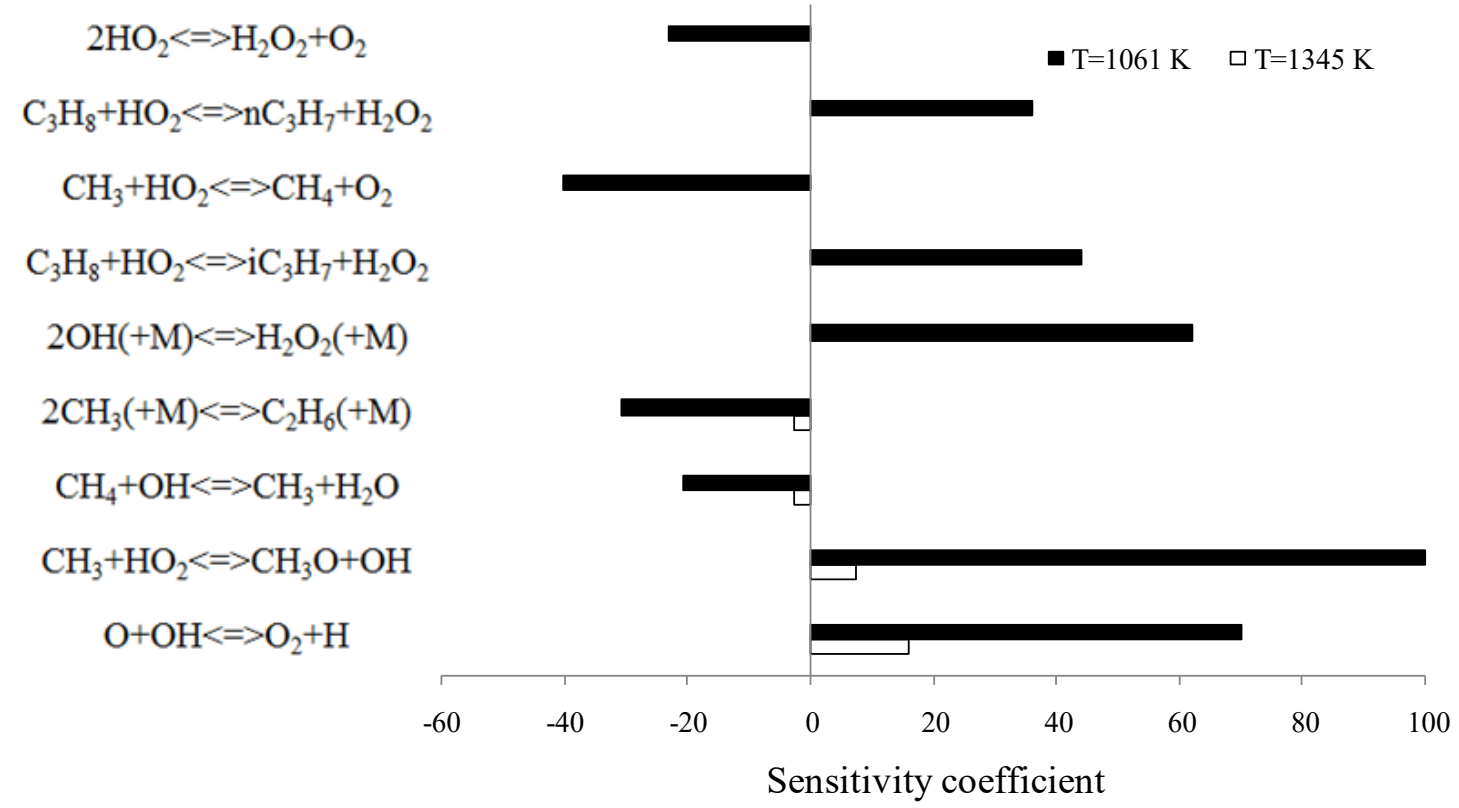

Figure 3. Sensitivity coefficient of $\mathrm{CNG} /$ air in shock tube, $\mathrm{P}=20 \mathrm{~atm}, 70 \% \mathrm{CH}_{4} / 20 \%$ $\mathrm{C}_{2} \mathrm{H}_{6} / 10 \% \mathrm{C}_{3} \mathrm{H}_{8}, \phi=0.5, \mathrm{~T}=1345$ and $1061 \mathrm{~K}$. 
Sensitivity analysis for different mixtures was performed at $1061 \mathrm{~K}, 20 \mathrm{~atm}, \phi=0.5$ and lean fuel (mixture 2) and $\phi=2.0$ and rich fuel (mixture 3). Figure 4 shows that for the lean fuel (mixture 2) and rich fuel (mixture 3), there were no significant reactions that were very different, and only the sensitivity coefficient was different. For both mixtures, reaction 34, $\mathrm{CH}_{3} \mathrm{O}+\mathrm{OH} \rightarrow \mathrm{CH}_{3}+\mathrm{HO}_{2}$, was the most sensitive. Heghes [20] stated that the most sensitive reaction for lean, stoichiometric and rich mixtures is $\mathrm{H}^{+} \mathrm{O}_{2} \rightarrow \mathrm{O}+\mathrm{OH}$, whereas in our study this reaction occupies the second highest place. In addition, because the reaction occurred at high pressure, reactions containing a third body $\mathrm{M}$, such as reaction $23, \mathrm{H}_{2} \mathrm{O}_{2}(+\mathrm{M}) \rightarrow 2 \mathrm{OH}(+\mathrm{M})$, a thermal decomposition reaction of hydrogen peroxide, also became sensitive under these conditions. The third body is a species other than the reactant molecule that carries energy in the uni-molecular decomposition process. Under the initial condition, when the system was pressurized, the magnitude of the initial pressure applied to the third body was equal to the initial pressure applied to the system. Based on Figure 4, the sensitivity coefficients for lean fuel were higher than those for rich fuel. This means that the effect of the inhibiting reaction for ignition in mixture 2 was greater than that in mixture 3 . Therefore, at $1061 \mathrm{~K}$ and $20 \mathrm{~atm}$, mixture 2 would have a larger IDT than mixture 3 . This was evident from the simulation result, where the IDT for mixture 2 was $3.81 \mathrm{~ms}$ whereas that for mixture 3 was $2.03 \mathrm{~ms}$.



Figure 4. Sensitivity coefficient of $\mathrm{CNG} /$ air in shock tube, $\mathrm{P}=20 \mathrm{~atm}, 70 \% \mathrm{CH}_{4} / 20 \%$ $\mathrm{C}_{2} \mathrm{H}_{6} / 10 \% \mathrm{C}_{3} \mathrm{H}_{8}, \mathrm{~T}=1061 \mathrm{~K}$, for two different mixtures, $\phi=2.0$ and 0.5

Sensitivity analysis for different pressures was performed at $\mathrm{T}=1370 \mathrm{~K}, \phi=2.0$, and two different initial pressures, $20 \mathrm{~atm}$ for mixture 4 and $1.1 \mathrm{~atm}$ for mixture 5 . At 1.1 and $20 \mathrm{~atm}$, the tenth most sensitive reactions were the same, but their sensitivity coefficients differed. At both pressures, reaction 2, the most sensitive reaction, became the basis for the combustion processes of hydrocarbon chain branching at high temperatures. This reaction occurred upon the consumption of one $\mathrm{H}$ atom and produced two radicals, $\mathrm{O}$ and $\mathrm{OH}$. As shown in Figure 5, reactions 30 and 11 affected the supply of $\mathrm{H}$ atoms for the termination stage. These reactions also had an inhibitory effect on the 
overall reaction rate of the two mixtures. However, their sensitivity coefficients were greater for mixture $5(1.1 \mathrm{~atm})$ than for mixture $4(20 \mathrm{~atm})$. Therefore, for the initial temperature of $1370 \mathrm{~K}$ and $\phi=2.0$, mixture 5 would have slower ignition than mixture 4 . This was evident from the simulation result, where the IDT for mixture 5 was $0.731 \mathrm{~ms}$ whereas that for mixture 4 was $0.0861 \mathrm{~ms}$.

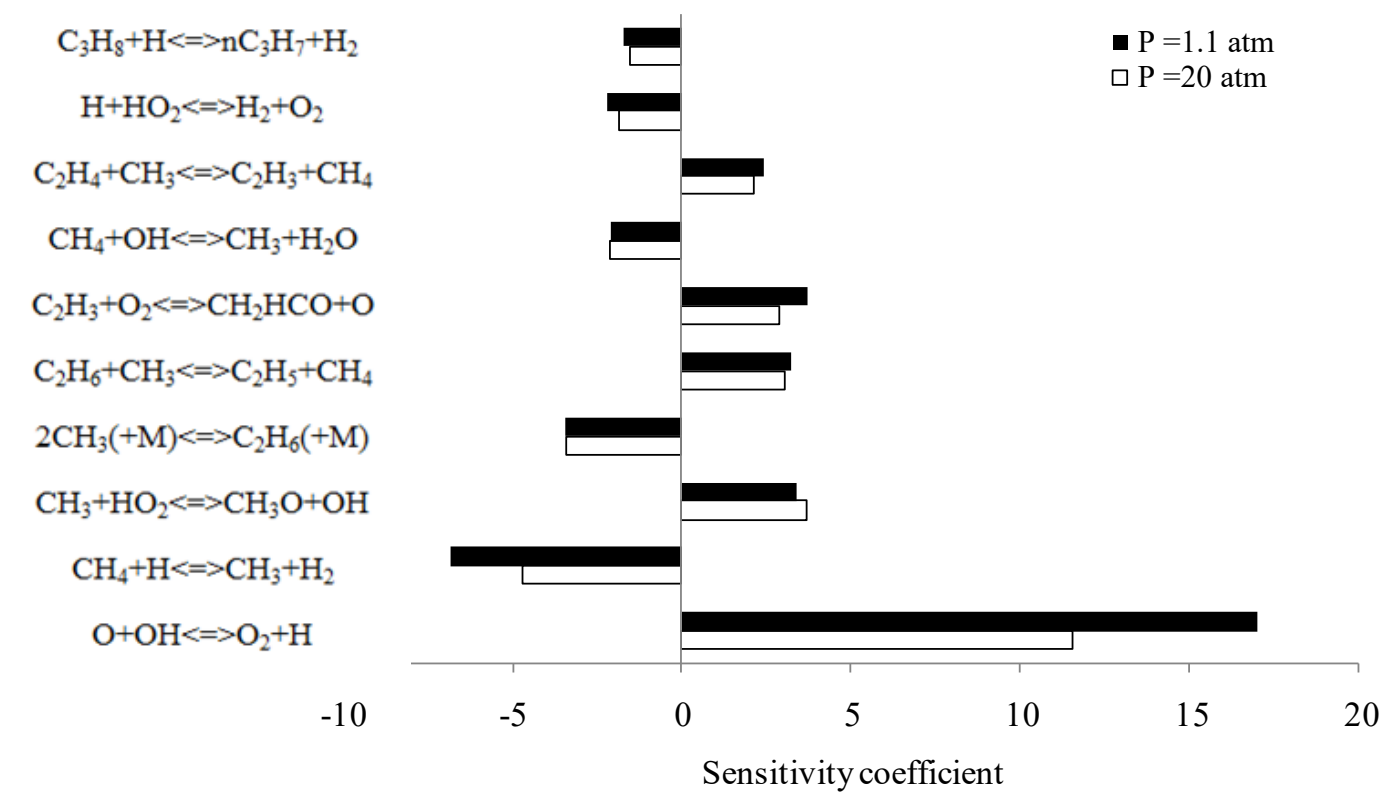

Figure 5. Sensitivity coefficient of $\mathrm{CNG} /$ air in shock tube, $\phi=2.0,70 \% \mathrm{CH}_{4} / 20 \%$ $\mathrm{C}_{2} \mathrm{H}_{6} / 10 \% \mathrm{C}_{3} \mathrm{H}_{8}, \mathrm{~T}=1370 \mathrm{~K}$, for two different pressures, $\mathrm{P}=1.1$ and $20 \mathrm{~atm}$.

The reaction analysis of $\mathrm{CH}_{4}, \mathrm{C}_{2} \mathrm{H}_{6}$, and $\mathrm{C}_{3} \mathrm{H}_{8}$ consumption for different temperatures was conducted at 20 atm, $\phi=0.5$, and $1345 \mathrm{~K}$ (mixture 1 ) and $1061 \mathrm{~K}$ (mixture 2). At $\mathrm{T}=1345 \mathrm{~K}, \mathrm{P}=20 \mathrm{~atm}$, and $\phi=0.5$, as shown in Table 5, the highest methane consumption occurred through $\mathrm{H}$ atom abstraction by $\mathrm{OH}$ radical attack to form methyl radicals. Ethane consumption under this condition also occurred through $\mathrm{H}$ atom abstraction, which was mostly due to $\mathrm{OH}$ radical attack. Furthermore, propane consumption largely occurred through $\mathrm{H}$ atom abstraction by $\mathrm{OH}$ radical attack and then by $\mathrm{O}, \mathrm{H}$, and $\mathrm{HO}_{2}$ forming isopropyl and normal propyl radicals. At the lower initial temperature of $1061 \mathrm{~K}$ for mixture 2 , the methane consumption stage was similar to that for mixture 1, i.e., the highest methane consumption occurred through $\mathrm{H}$ atom abstraction by $\mathrm{OH}$ radicals. Furthermore, ethane consumption at lower temperature also mainly occurred through $\mathrm{H}$ atom abstraction by $\mathrm{OH}$ attack. However, at this lower temperature, $\mathrm{O}$ radical attack more strongly influenced $\mathrm{H}$ atom abstraction than $\mathrm{H}$ radical attack.

The reaction analysis of $\mathrm{CH}_{4}, \mathrm{C}_{2} \mathrm{H}_{6}$, and $\mathrm{C}_{3} \mathrm{H}_{8}$ consumption for different mixtures was conducted at $1061 \mathrm{~K}, 20 \mathrm{~atm}, \phi=0.5$ (mixture 2) and $\phi=2.0$ (mixture 3). The results for mixture 3 showed that the highest $\mathrm{CH}_{4}$ consumption derived from reaction 30 , which had the smallest consumption of $\mathrm{CH}_{4}$ in mixture $2(\phi=0.5)$. This indicated that the abstraction of methane in a fuel-rich mixture was due to $\mathrm{H}$ radicals and not $\mathrm{OH}$ radicals, because the equivalent ratio was large, and there was excess fuel and oxygen deficiency. As a result, there was not enough oxygen to oxidize the remaining fuel, and therefore, the production of radicals such as $\mathrm{OH}$ radicals was reduced. Furthermore, ethane consumption in mixture 3 occurred through $\mathrm{H}$ atom abstraction, which was mostly due to $\mathrm{OH}$ radicals. This was similar to what was observed in mixture 2, except that the $\% \mathrm{OH}$ 
radical consumption declined in mixture 3 , which has higher $\phi$. This is because the mixture had been deprived of oxygen, and therefore, the formation of $\mathrm{OH}$ radicals was reduced. This trend was similar to propane consumption, where $\mathrm{H}$ atom abstraction occurred mostly because of a decrease in the $\% \mathrm{OH}$ radical attack. The reaction analysis of $\mathrm{CH}_{4}, \mathrm{C}_{2} \mathrm{H}_{6}$, and $\mathrm{C}_{3} \mathrm{H}_{8}$ consumption for different pressures was performed at $1,370 \mathrm{~K}$, $\phi=2.0$, and $20 \mathrm{~atm}$ (mixture 4) and $1.1 \mathrm{~atm}$ (mixture 5). At $\mathrm{T}=1370 \mathrm{~K}, \mathrm{P}=20 \mathrm{~atm}$, and $\phi=2.0$, methane/ethane/propane consumption again showed $\mathrm{H}$ atom abstraction by $\mathrm{H}$ radicals to form methyl, ethyl, and normal propyl radicals. Then, at the lower pressure of $1.1 \mathrm{~atm}$, the stages of methane/ethane/propane consumption showed that the highest similarity occurred through $\mathrm{H}$ atom abstraction by active radicals attack, forming $\mathrm{H}$ radicals that produce methyl, ethyl, and n-propyl radicals. However, at lower pressure, unlike the previous condition, the lack of involvement of $\mathrm{HO}_{2}$ radical attacks on propane by $\mathrm{O}_{2}$ to produce $\mathrm{HO}_{2}$ radicals was lower than in the previous condition (higher $\mathrm{P}$ conditions), and the concentrations of $\mathrm{HO}_{2}$ were therefore lower at $1.1 \mathrm{~atm}$ conditions.

Table 5. \% $\mathrm{CH}_{4}, \mathrm{C}_{2} \mathrm{H}_{6}$, and $\mathrm{C}_{3} \mathrm{H}_{8}$ consumption of each reaction involved (mixture 1).

\begin{tabular}{|c|c|c|c|c|}
\hline $\begin{array}{c}\text { No. } \\
\text { Reaction }\end{array}$ & Reaction & $\begin{array}{c}\% \mathrm{CH}_{4} \\
\text { Consumptio } \\
\mathrm{n}\end{array}$ & $\begin{array}{c}\% \mathrm{C}_{2} \mathrm{H}_{6} \\
\text { Consumptio } \\
n\end{array}$ & $\begin{array}{c}\% \mathrm{C}_{3} \mathrm{H}_{8} \\
\text { Consumptio } \\
\mathrm{n}\end{array}$ \\
\hline 30 & $\mathrm{CH}_{4}+\mathrm{H} \rightarrow \mathrm{CH}_{3}+\mathrm{H}_{2}$ & 25.2 & & \\
\hline 31 & $\mathrm{CH}_{4}+\mathrm{OH} \rightarrow \mathrm{CH}_{3}+\mathrm{H}_{2} \mathrm{O}$ & 45.3 & & \\
\hline 32 & $\mathrm{CH}_{4}+\mathrm{O} \rightarrow \mathrm{CH}_{3}+\mathrm{OH}$ & 28.5 & & \\
\hline 130 & $\mathrm{C}_{2} \mathrm{H}_{6}+\mathrm{CH}_{3} \rightarrow \mathrm{C}_{2} \mathrm{H}_{5}+\mathrm{CH}_{4}$ & & 6.9 & \\
\hline 131 & $\mathrm{C}_{2} \mathrm{H}_{6}+\mathrm{H} \rightarrow \mathrm{C}_{2} \mathrm{H}_{5}+\mathrm{H}_{2}$ & & 20.7 & \\
\hline 132 & $\mathrm{C}_{2} \mathrm{H}_{6}+\mathrm{O} \rightarrow \mathrm{C}_{2} \mathrm{H}_{5}+\mathrm{OH}$ & & 18.4 & \\
\hline 133 & $\mathrm{C}_{2} \mathrm{H}_{6}+\mathrm{OH} \rightarrow \mathrm{C}_{2} \mathrm{H}_{5}+\mathrm{H}_{2} \mathrm{O}$ & & 53.7 & \\
\hline 231 & $\begin{array}{c}\mathrm{C}_{3} \mathrm{H}_{8}+\mathrm{HO}_{2} \rightarrow \mathrm{nC}_{3} \mathrm{H}_{7}+\mathrm{H}_{2} \\
\mathrm{O}_{2}\end{array}$ & & & 1.3 \\
\hline 233 & $\mathrm{C}_{3} \mathrm{H}_{8}+\mathrm{OH} \rightarrow \mathrm{nC}_{3} \mathrm{H}_{7}+\mathrm{H}_{2} \mathrm{O}$ & & & 26 \\
\hline 234 & $\mathrm{C}_{3} \mathrm{H}_{8}+\mathrm{OH} \rightarrow \mathrm{iC}_{3} \mathrm{H}_{7}+\mathrm{H}_{2} \mathrm{O}$ & & & 17.3 \\
\hline 235 & $\mathrm{C}_{3} \mathrm{H}_{8}+\mathrm{O} \rightarrow \mathrm{nC}_{3} \mathrm{H}_{7}+\mathrm{OH}$ & & & 18.9 \\
\hline 236 & $\mathrm{C}_{3} \mathrm{H}_{8}+\mathrm{O} \rightarrow \mathrm{iC}_{3} \mathrm{H}_{7}+\mathrm{OH}$ & & & 12.4 \\
\hline 237 & $\mathrm{C}_{3} \mathrm{H}_{8}+\mathrm{H} \rightarrow \mathrm{iC}_{3} \mathrm{H}_{7}+\mathrm{H}_{2}$ & & & 9.4 \\
\hline 238 & $\mathrm{C}_{3} \mathrm{H}_{8}+\mathrm{H} \rightarrow \mathrm{nC}_{3} \mathrm{H}_{7}+\mathrm{H}_{2}$ & & & 13.2 \\
\hline
\end{tabular}

\section{Rate Analysis (Reaction Contribution of $\mathrm{CO}_{2}, \mathrm{CO}$, and $\mathrm{CH}_{2} \mathrm{O}$ Production)}

The rate analysis of $\mathrm{CO}, \mathrm{CO}_{2}$, and $\mathrm{CH}_{2} \mathrm{O}$ production was performed for different temperatures, different mixtures, and different pressures. For mixture 1, $\mathrm{CO}_{2}$ was produced by some reactions, i.e., from $34.7 \% \mathrm{HCOH}$ that reacted with oxygen, $36.4 \%$ $\mathrm{CO}$ that reacted with $\mathrm{OH}$ radicals, $26.9 \% \mathrm{HCCO}$ that reacted with oxygen, and, only slightly, by $1.3 \% \mathrm{CH}_{2} \mathrm{CO}$ radicals that reacted with $\mathrm{O}$. Then, most $\mathrm{CO}(73.8 \%)$ was produced by the formal radical through $\mathrm{H}$ atom abstraction by assault reactions involving oxygen and a third body. Furthermore, $\mathrm{HCOH}$ produced $99 \%$ of the $\mathrm{CH}_{3}$ that reacted with hydroxyl radicals. Thus, the main reaction pathways of $\mathrm{CO}_{2}$ production under conditions of a high temperature of $1345 \mathrm{~K}, \mathrm{P}=20 \mathrm{~atm}$, and $\phi=0.5$ was $\mathrm{CH}_{4} \rightarrow \mathrm{CH}_{3} \rightarrow \mathrm{HCOH} \rightarrow \mathrm{CO}_{2}$. At the lower temperature of $1061 \mathrm{~K}$, compared with mixture $1(1345 \mathrm{~K})$, a significant difference was observed. Most of the formation of $\mathrm{CO}_{2}$ was due to $\mathrm{CO}$ that reacted with $\mathrm{OH}, \mathrm{HO}_{2}$, and $\mathrm{O}$ radicals as well as the third body. This indicated that at the lower 
temperature, the effect of $\mathrm{CO}$ was higher than that of $\mathrm{HCOH}$ in $\mathrm{CO}_{2}$ formation. Thus, the $\mathrm{CO}_{2}$ production pathway at the lower temperature of $1061 \mathrm{~K}, 20 \mathrm{~atm}$, and $\phi=0.5$ was $\mathrm{CH}_{4} \rightarrow \mathrm{CH}_{3} \rightarrow \mathrm{CH}_{3} \mathrm{O} \rightarrow \mathrm{CH}_{2} \mathrm{O} \rightarrow \mathrm{HCO} \rightarrow \mathrm{CO} \rightarrow \mathrm{CO}_{2}$.

Mixture 3 (rich fuel) and lean fuel show a small noticeable difference, namely, that $\mathrm{CO}_{2}$ formation for the rich fuel for $\mathrm{HCCO}$ reaction with oxygen was more dominant than $\mathrm{HCOH}$ reaction with oxygen. This is in contrast with the lean fuel composition. Thus, the $\mathrm{CO}_{2}$ production pathway at $1061 \mathrm{~K}, 20 \mathrm{~atm}$, and $\phi=2.0$ was $\mathrm{CH}_{4} \rightarrow \mathrm{CH}_{3} \rightarrow \mathrm{CH}_{3} \mathrm{O} \rightarrow \mathrm{CH}_{2} \mathrm{O} \rightarrow \mathrm{HCO} \rightarrow \mathrm{CO} \rightarrow \mathrm{CO}_{2}$. The results further showed that the difference in initial pressure results in a slightly different reaction. At lower pressure, $\mathrm{CO}_{2}$ production was dominated by $\mathrm{HCOH}$ reacting with $\mathrm{O}_{2}$. At higher pressure, $\mathrm{CO}_{2}$ production was dominated by $\mathrm{HO}_{2}$ and $\mathrm{OH}$ radical attack on $\mathrm{CO}$. That is because the reaction involving a third body for $\mathrm{CO}$ production as in a mixture with high pressure was reduced at low pressure, and the rate of formation of $\mathrm{CO}_{2}$ from $\mathrm{CO}$ was therefore reduced. Meanwhile, $\mathrm{CO}$ formation at high pressure was dominated more by third body attack against $\mathrm{HCO}$, whereas at low pressure it was dominated by oxygen attack against HCO. Thus, the reaction pathway of $\mathrm{CO}_{2}$ production at $1370 \mathrm{~K}, \phi=2.0$, and $20 \mathrm{~atm}$ was $\mathrm{CH}_{4} \rightarrow \mathrm{CH}_{3} \rightarrow \mathrm{CH}_{3} \mathrm{O} \rightarrow \mathrm{CH} 2 \mathrm{O} \rightarrow \mathrm{HCO} \rightarrow \mathrm{CO} \rightarrow \mathrm{CO}_{2}$. Meanwhile, the reaction pathway of $\mathrm{CO}_{2}$ production at $1370 \mathrm{~K}, \phi=2.0$, and 1.1 atm was $\mathrm{CH}_{4} \rightarrow \mathrm{CH}_{3} \rightarrow \mathrm{HCOH} \rightarrow \mathrm{CO}_{2}$. The simulation results conducted by Heghes [13] for lean, stoichiometric and rich mixtures exhibited also that the main reaction pathway of $\mathrm{CO}_{2}$ production is $\mathrm{CH}_{4} \rightarrow \mathrm{CH}_{3} \rightarrow \mathrm{HCOH} \rightarrow \mathrm{CO}_{2}$.

\section{Simulation}

The simulation aimed to see the IDT profile without a laboratory experiment. It was conducted with four variables: initial pressure, equivalent ratio, diluents composition, and CNG composition. The fuel composition of $88 \% \mathrm{CH}_{4} / 8 \% \mathrm{C}_{2} \mathrm{H}_{6} / 4 \% \mathrm{C}_{3} \mathrm{H}_{8}$ was used for various initial pressure simulations, equivalent ratio variations, diluents compositions, and CNG compositions. This composition was adjusted based on the Directorate General of Oil and Gas's 2011 specification, namely, that CNG fuel marketed domestically must contain a minimum of $77 \% \mathrm{CH}_{4}$ and a maximum of $8 \% \mathrm{C}_{2} \mathrm{H}_{6}$ and $4 \% \mathrm{C}_{3} \mathrm{H}_{8}$.

\section{Varied Pressure}

Figure 6 shows the IDT profile in the mixture of $88 \% \mathrm{CH}_{4} / 8 \% \mathrm{C}_{2} \mathrm{H}_{6} / 4 \% \mathrm{C}_{3} \mathrm{H}_{8}$ for $75 \% \mathrm{~N}_{2}$, $\phi=1.0, \mathrm{~T}=1100$ to $1500 \mathrm{~K}$, and 2, 15, and $30 \mathrm{~atm}$. Based on Figure 6, with higher initial pressure and initial temperature, the IDT is shorter and fuel would be burned quickly. The same trends were also shown by the results of research and experiments conducted by Healy [7]. When the temperature increases, the IDT decreases. This occurs because the increase in temperature increases the kinetic energy. Increased kinetic energy causes an increased number of collisions of molecules. Based on the simulation result, the slowest ignition result was $21.5 \mathrm{~ms}(\mathrm{P}=2 \mathrm{~atm}, \mathrm{~T}=1100 \mathrm{~K}, \phi=1.0)$ and the smallest IDT was 0.042 ms $(\mathrm{P}=30$ atm, $\mathrm{T}=1500 \mathrm{~K}, \phi=1.0)$.

\section{Varied Equivalent Ratio}

The simulation with varied equivalent ratios was conducted to determine the influence of the fuel composition in air with IDT. The IDT profile for varied mixture compositions was carried out for 2, 15, and $30 \mathrm{~atm}$ in the temperature range of 900-1500 K. This simulation was conducted with a different range of initial $\mathrm{T}$ values. This was done to see the point of intersection of the IDT. Figure 7(a) shows the IDT profile in the mixture of $88 \% \mathrm{CH}_{4} / 8 \% \mathrm{C}_{2} \mathrm{H}_{6} / 4 \% \mathrm{C}_{3} \mathrm{H}_{8}$ for $75 \% \mathrm{~N}_{2}, \mathrm{P}=2 \mathrm{~atm}, \mathrm{~T}=900-1500 \mathrm{~K}$, for three different $\phi$ 
values. Based on Figure 7(a), the more fuel, the slower is the IDT. This occurred at above $900 \mathrm{~K}$, and the opposite condition occurred at $900 \mathrm{~K}$ and below. This caused the intersection in the graph at a temperature of $900 \mathrm{~K}$. In Figure 7(b), with increasing initial pressure (from 2 to $15 \mathrm{~atm}$ ), the intersection point moved to a higher temperature, $1000 \mathrm{~K}$, and the IDT reduced, as indicated by the graph. This change occurred because, as mentioned previously, the increase in initial pressure causes the IDT to reduce. In Figure 7(c), the same pattern as in Figures 7(a) and 7(b) was observed; however, as shown here, by increasing the initial pressure to $30 \mathrm{~atm}$, the intersection point moves to a higher temperature of $1,100 \mathrm{~K}$ and the IDT reduces.

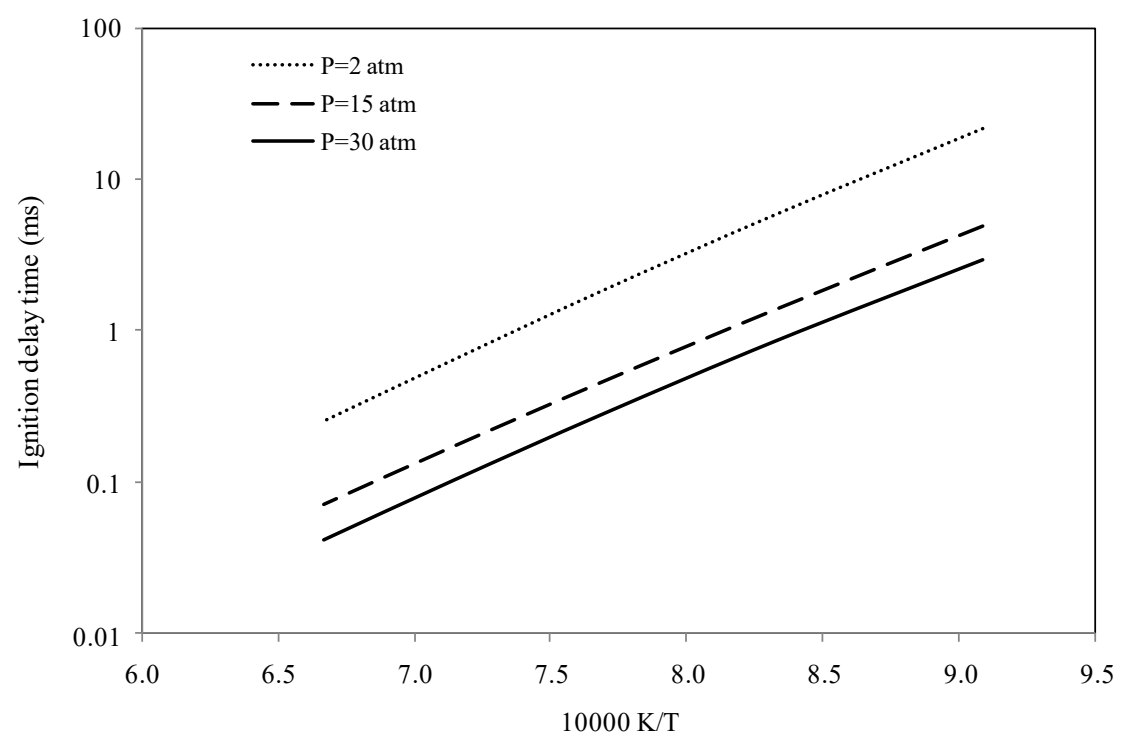

Figure 6. IDT (ms) in mixture of $88 \% \mathrm{CH}_{4} / 8 \% \mathrm{C}_{2} \mathrm{H}_{6} / 4 \% \mathrm{C}_{3} \mathrm{H}_{8}$ for $75 \% \mathrm{~N}_{2}, \phi=1.0$ toward initial pressure.

Based on Figures 7 in condition 1 where the temperature is lower, an increase in $\phi$ will cause the IDT to reduce. This is because at lower temperature, the large fuel concentration in air will lead to a higher concentration of radicals, causing the ignition process to become faster than with a small amount of fuel in air. In condition 2 (higher temperature), decreasing $\phi$ will result in the IDT reducing. This is because at higher temperature, the large oxygen concentration in air will lead to a higher concentration of active radicals, and this will reduce the IDT compared with the case of higher fuel concentration in the air. Thus, based on various equivalent ratios, it can be concluded that the slowest IDT $(1100-1500 \mathrm{~K})$ is $37.2 \mathrm{~ms}(\mathrm{P}=2 \mathrm{~atm}, \mathrm{~T}=1100 \mathrm{~K}$, and $\phi=2.0)$ and the fastest IDT $(1100-1500 \mathrm{~K})$ is $0.033 \mathrm{~ms}(\mathrm{P}=30 \mathrm{~atm}, \mathrm{~T}=1500 \mathrm{~K}$, and $\phi=0.5)$.

\section{Varied Diluents Compositions}

Figure 8 shows the IDT profile in the mixture of $88 \% \mathrm{CH}_{4} / 8 \% \mathrm{C}_{2} \mathrm{H}_{6} / 4 \% \mathrm{C}_{3} \mathrm{H}_{8}$ for $\mathrm{P}=15$ atm, $\mathrm{T}=1100-1500 \mathrm{~K}$, and three different diluents compositions $\left(\mathrm{N}_{2}\right): 65 \% \mathrm{~N}_{2}, 75 \% \mathrm{~N}_{2}$, and $85 \% \mathrm{~N}_{2}$. Based on Figure 8, the lower the diluents composition, the slower is the IDT. Increasing diluents composition will lower the fuel composition and oxygen so that the concentration of active radicals tends to decrease and the IDT decreases. 


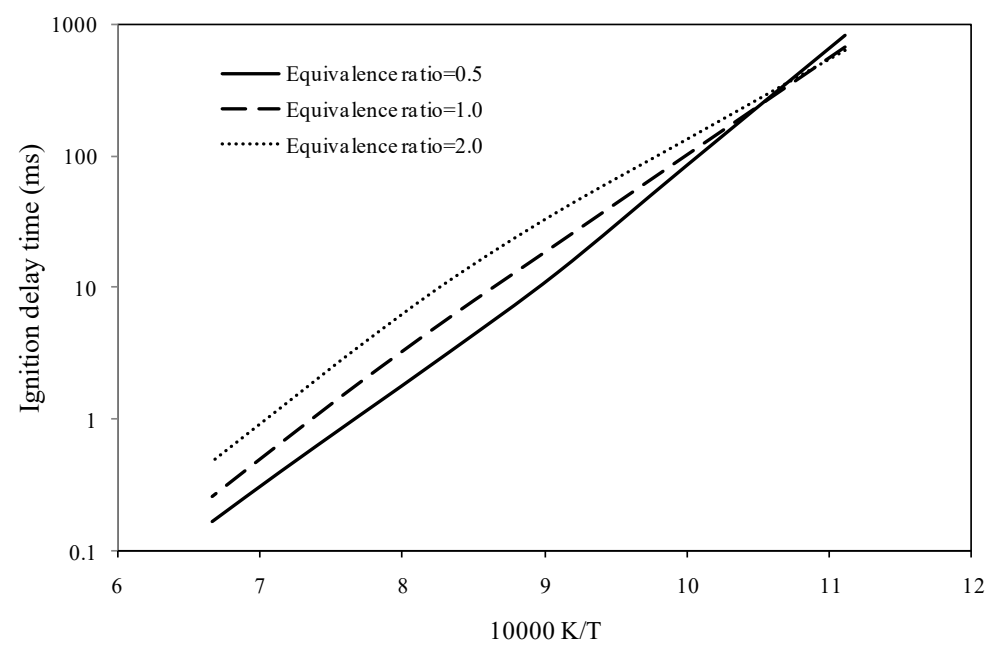

(a)

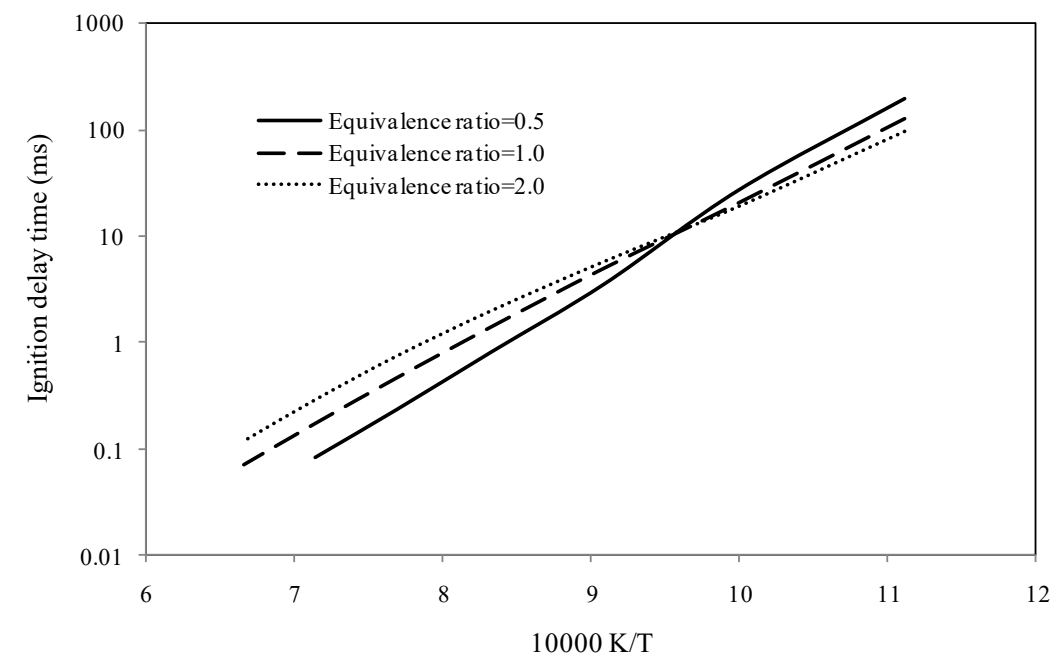

(b)



(c)

Figure 7. IDT simulation at $88 \% \mathrm{CH}_{4} / 8 \% \mathrm{C}_{2} \mathrm{H}_{6} / 4 \% \mathrm{C}_{3} \mathrm{H}_{8}$ for $75 \% \mathrm{~N}_{2}$, varying $\phi$, and (a) $\mathrm{P}=2 \mathrm{~atm}$, (b) $\mathrm{P}=15 \mathrm{~atm}$, and (c) $\mathrm{P}=30 \mathrm{~atm}$ 


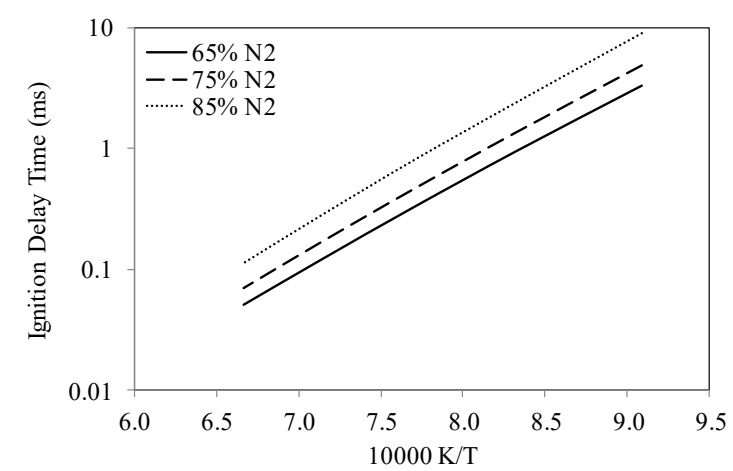

Figure 8. IDT simulation at $88 \% \mathrm{CH}_{4} / 8 \% \mathrm{C}_{2} \mathrm{H}_{6} / 4 \% \mathrm{C}_{3} \mathrm{H}_{8}$ for $\phi=1.0, \mathrm{P}=15 \mathrm{~atm}$, for various diluents $\left(\mathrm{N}_{2}\right)$ compositions.

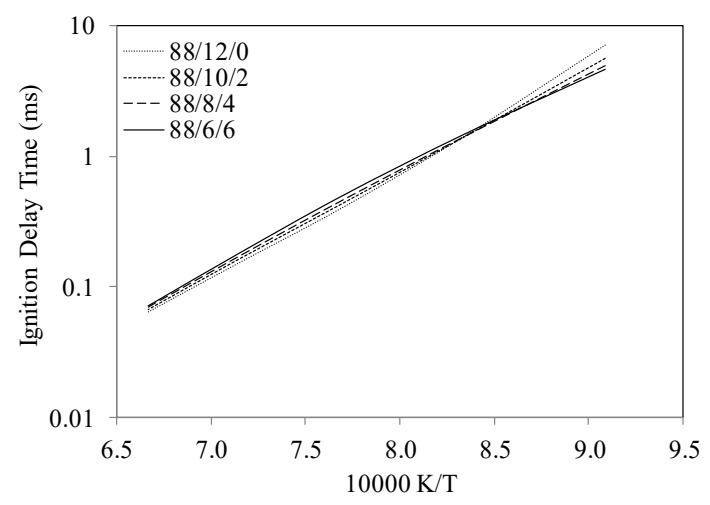

(a)

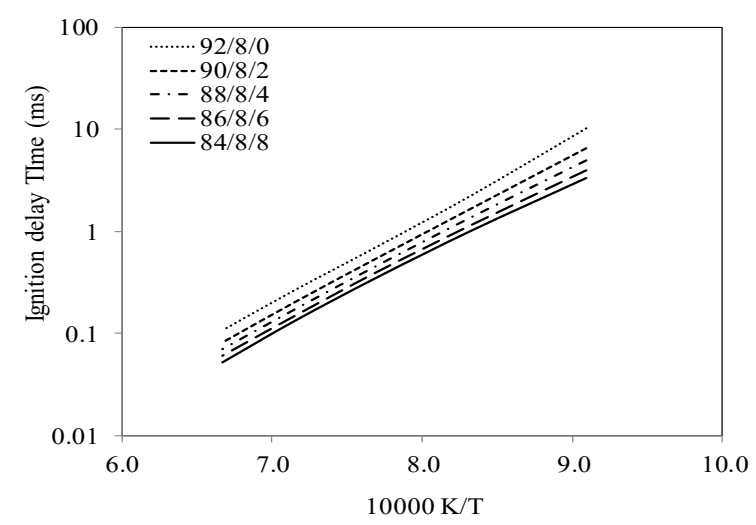

(b)

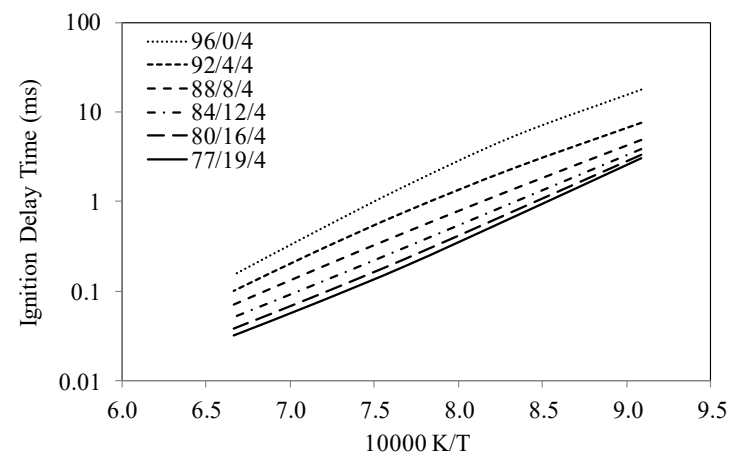

(c)

Figure 9. IDT simulation at $75 \% \mathrm{~N}_{2}, \phi=1.0, \mathrm{P}=15$ atm for various $\mathrm{CNG}$ compositions and (a) constant methane, (b) constant ethane, and (c) constant propane 


\section{Varied CNG Composition}

Figures 9 show the IDT profile for a mixture of $5 \% \mathrm{~N}_{2}, \mathrm{P}=15$ atm, $\mathrm{T}=1100-1500 \mathrm{~K}$. Figure 9(a) shows that at the initial temperature above $1100 \mathrm{~K}$, the increase in ethane and decrease in propane will result in the IDT decreasing. Figures 9(b) and 9(c) indicate that for a constant composition of ethane or propane, increasing the methane composition will cause the IDT to increase, and therefore, ignition will be slower.

\section{CONCLUSIONS}

The kinetics reaction model of $\mathrm{CNG}$ combustion has been successfully developed for mixed $\mathrm{CH}_{4} / \mathrm{C}_{2} \mathrm{H}_{6} / \mathrm{C}_{3} \mathrm{H}_{8} / \mathrm{O}_{2} / \mathrm{N}_{2}$ in the temperature range of 1039-1553 $\mathrm{K}$, pressure range of 1.1-40 atm, and equivalent ratio $\phi=0.5,1$, and 2 using a shock tube. The IDT profile for $\mathrm{CNG}$ combustion in a shock tube was very well reproduced by the kinetics model. The sensitivity analysis result shows that the most sensitive reaction, whose reaction rate increases at $\mathrm{T}=1345 \mathrm{~K}$, is reaction $2(16.135), \mathrm{O}_{2}+\mathrm{H} \rightarrow \mathrm{O}+\mathrm{OH}$, and at $\mathrm{T}=1061 \mathrm{~K}$ is reaction 34 (99.954), $\mathrm{CH}_{3} \mathrm{O}+\mathrm{OH} \rightarrow \mathrm{CH}_{3}+\mathrm{HO}_{2}$. The most sensitive reaction with different mixtures is reaction 34 (99.954) for $\phi=0.5$ and (24.294) for $\phi=2.0$. The most sensitive reaction with various pressures is reaction 2 (11.569) for $\mathrm{P}=20$ atm and (16.987) for $\mathrm{P}=1.1$ atm. The consumption rate of $\mathrm{CH}_{4} / \mathrm{C}_{2} \mathrm{H}_{6} / \mathrm{C}_{3} \mathrm{H}_{8}$ mostly occurs through the abstraction of $\mathrm{H}$ atoms from $\mathrm{OH}$ radical attack for a high fuel mixture and from $\mathrm{H}$ radical attack for low fuel mixture. The analysis production rate result shows that $\mathrm{CO}_{2}$ was mostly produced by $\mathrm{CO}$ that reacted with $\mathrm{HO}_{2}$. Most $\mathrm{CO}$ was produced by formyl radicals that reacted with oxygen or a third body. Then, formaldehyde was produced by $\mathrm{CH}_{3} \mathrm{O}$ radicals that reacted with a third body. In general, $\mathrm{CO}_{2}$ formation occurs as $\mathrm{CH}_{4} \rightarrow \mathrm{CH}_{3} \rightarrow \mathrm{CH}_{3} \mathrm{O} \rightarrow \mathrm{CH}_{2} \mathrm{O} \rightarrow \mathrm{HCO} \rightarrow \mathrm{CO} \rightarrow \mathrm{CO}_{2}$. The simulation result shows that the higher the initial $\mathrm{T}$ and $\mathrm{P}$, the lower is the IDT, and this will result in ignition becoming faster and the fuel burning quickly. Meanwhile, the higher the fuel temperature, the higher is the IDT, and ignition will occur much slowly, but the result will contradict that at low temperature. Furthermore, the higher the percentage of diluents that have been used, the faster is the IDT. The slowest IDT for the composition of $88 \% \mathrm{CH}_{4} / 8 \% \mathrm{C}_{2} \mathrm{H}_{6} / 4 \% \mathrm{C}_{3} \mathrm{H}_{8}$ with the initial temperature range of $1100-1500 \mathrm{~K}$ is $37.2 \mathrm{~ms}(\mathrm{P}=2 \mathrm{~atm}, \mathrm{~T}=1100 \mathrm{~K}$, and $\phi=2.0)$ and the fastest IDT is $0.033 \mathrm{~ms}(\mathrm{P}=30 \mathrm{~atm}, \mathrm{~T}=1,500 \mathrm{~K}$, and $\phi=0.5)$. For constant ethane and propane composition, the increase in methane composition will cause slower ignition.

\section{ACKNOWLEDGEMENT}

We would like to thank the Directorate General of Oil and Gas, Ministry of Energy and Mineral Resources Republic of Indonesia for financial support to this study.

\section{REFERENCES}

[1] Yusaf T, Baker P, Hamawand I, Noor M. Effect of compressed natural gas mixing on the engine performance and emissions. International Journal of Automotive and Mechanical Engineering. 2013;8:1416-29.

[2] Zainal Arifin, Sukoco. Pengendalian Polusi Kendaraan. Bandung: Alfabeta; 2009.

[3] Hu E, Li X, Meng X, Chen Y, Cheng Y, Xie Y, et al. Laminar flame speeds and ignition delay times of methane-air mixtures at elevated temperatures and pressures. Fuel. 2015;158:1-10. 
[4] Mohanamurugan S, Sendilvelan S. Emission and combustion characteristics of different fuels in HCCI engine. International Journal of Automotive and Mechanical Engineering.3:279-92.

[5] Richards GA, McMillian MM, Gemmen RS, Rogers WA, Cully SR. Issues for low-emission, fuel-flexible power systems. Progress in Energy and Combustion Science. 2001;27:141-69.

[6] Ibrahim TK, Rahman MM. Effect of compression ratio on the performance of different strategies for gas turbine. International Journal of Automotive and Mechanical Engineering 2014;9:1747-57.

[7] Smidth FL. Preheater calciner systems. In: FLSmidth, editor. 2011.

[8] Nik Rosli Abdullah, Nafis Syabil Shahruddin, Rizalman Mamat, Aman Mohd. Ihsan Mamat, Zulkifli A. Effects of air intake pressure on the engine performance, fuel economy and exhaust emissions of a small gasoline engine. Journal of Mechanical Engineering and Sciences. 2014;6:949-58.

[9] Lamoureux N, Paillard CE. Natural gas ignition delay times behind reflected shock waves: Application to modelling and safety. Shock Waves. 2003;13:57-68.

[10] Zhang Y, Jiang X, Wei L, Zhang J, Tang C, Huang Z. Experimental and modeling study on auto-ignition characteristics of methane/hydrogen blends under engine relevant pressure. International Journal of Hydrogen Energy. 2012;37:19168-76.

[11] Held TJ, Dryer FL. A comprehensive mechanism for methanol oxidation. International Journal of Chemical Kinetics. 1998;30:805-30.

[12] Huang J, Bushe WK. Experimental and kinetic study of autoignition in methane/ethane/air and methane/propane/air mixtures under engine-relevant conditions. Combustion and Flame. 2006;144:74-88.

[13] Healy D, Curran HJ, Simmie JM, Kalitan DM, Zinner CM, Barrett AB, et al. Methane/ethane/propane mixture oxidation at high pressures and at high, intermediate and low temperatures. Combustion and Flame. 2008;155:441-8.

[14] Beerer DJ. Autoignition of methane, ethane, propane and hydrogen in turbulent high pressure and temperature flows. University of California, Irvine; 2009.

[15] Spesifikasi Bahan Bakar Gas Jenis CNG untuk Transportasi yang Dipasarkan di Dalam Negeri. 2011.

[16] Marinov NM, Pitz WJ, Westbrook CK, Vincitore AM, Castaldi MJ, Senkan SM, et al. Aromatic and polycyclic aromatic hydrocarbon formation in a laminar premixed n-butane flame. Combustion and Flame. 1998;114:192-213.

[17] CHEMKIN. 2015.

[18] Atmaca M. Efficiency analysis of combined cogeneration systems with steam and gas turbines. Energy Sources, Part A: Recovery, Utilization, and Environmental Effects. 2010;33:360-9.

[19] Bourque G, Healy D, Curran H, Zinner C, Kalitan D, de Vries J, et al. Ignition and flame speed kinetics of two natural gas blends with high levels of heavier hydrocarbons. Journal of Engineering for Gas Turbines and Power. 2009;132:021504-.

[20] Hegheș CI. C1-C4 hydrocarbon oxidation mechanism. 2006. 